\title{
The Creative Application of Incentive Method in the Management of Innovative Development of Higher Vocational Students
}

\author{
Qixin Gao \\ Hunan Vocational College of Modern Logistics, Changsha 410001, China \\ 455385116@qq.com
}

\begin{abstract}
Incentive way is an important educational means in contemporary education; many students need incentive way to improve their comprehensive quality. Especially in the education of higher vocational students, it is more necessary to adopt the incentive teaching method. Therefore, the reasonable and effective use of incentive teaching is a problem that current schools and teachers should focus on. In this paper, the author mainly analyzes the problems in the education of higher vocational students and gives reasonable and effective incentive teaching methods to manage higher vocational students.
\end{abstract}

Keywords: higher vocational students; incentive teaching methods; reasonable use.

\section{Introduction}

The management of higher vocational students often causes headache for teachers and students. Higher vocational students are active enough, but their self-control is very poor, which leads to their low exam results and great school management difficulty. The school aims at problems and characteristics of higher vocational students, adopts incentive way to better manage higher vocational students, so that higher vocational students can better restrain themselves, actively learn and improve their comprehensive quality. The reasonable use of incentive way can make higher vocational students not waste the precious time and complete their studies better.

\section{Problem in the Education of Higher Vocational Students}

Compared with other undergraduate education, there are still many problems in the education of higher vocational students, educators can only improve the teaching efficiency of higher vocational education by adopting teaching methods for these problems. Comprehensive analysis and development, modern high vocational students have problems such as lack of confidence, lack of learning interest and poor self-discipline. The author conducts concrete analysis of these three points in order to take measures.

\subsection{Lack of Confidence}

With the vigorous development of the national education cause, the number of college students has been a giant leap, but in the end, due to the limitations of the college entrance examination scores, students are graded. College students are divided into undergraduate and junior college graduate, and the undergraduate is divided into first tier universities and second tier universities. The division of grades makes the junior college students have the idea that they are the worst college students, and the junior college students do not make good grades in the high school, so long-term "poor students" greatly reduce their self-confidence, so they have feeling of inferiority, and act is overcautious. The inferiority complex of higher vocational students hinders their development, so that higher vocational students have no hope for learning, even give up learning, waste precious life in Internet bar, novels, constantly paralyze them, finally affect their life direction, give up his ideals of life. Therefore, teachers should use incentive way make students regain their self-confidence, stop self-degradation, seek their own ideals of life and strive to achieve it. 


\subsection{Lack of Learning Interest}

Starting from high school, higher vocational students are not among the ranks of good students, their study was to do things carelessly at that time, their learning enthusiasm was very low, and the problems that they did not understand asked teachers or classmates. The long-term abandonment of knowledge has made the knowledge loophole of higher vocational students become bigger and bigger, and they are getting harder and harder to make up, the students are gradually bored with learning and are not interested in learning. When they go to higher vocational schools, the students' learning interest is almost lost, they copy for the homework, and they can't copy and not pay homework. This vicious circle makes the academic achievement of higher vocational student worse, which affects the development of higher vocational students. Students will indulge themselves, waste time at random, skip classes all day, and stay in Internet bar. Finally, their studies could not be completed, and did not learn anything in three years at university.

\subsection{Lack of Self-discipline}

Higher vocational students are accustomed to the teaching mode when high school teachers only like students with good grades, therefore, when they go to college, higher vocational students are not as standardized as high school, and because the universities do not constrain students, higher vocational students are more undisciplined and do everything at will, never consider what to do as a student and what not to do. In college, poor self-discipline is very unfavorable to the development of students. Therefore, teachers should train students' self-discipline awareness through incentive way, make high vocational students standardize their own lifestyles, and make effective use of time and do not waste time. Only the improvement of self-discipline can make higher vocational students devote themselves to studying, and eventually graduate smoothly and find a proper job.

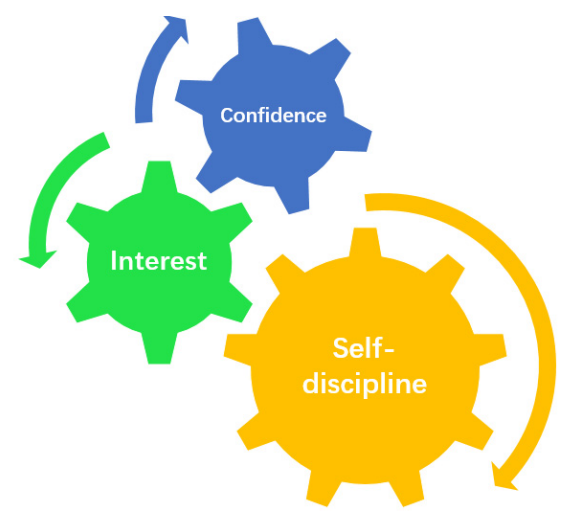

Fig. 1 Main causes of depression

\section{Use Incentive Way to Effectively Manage Higher Vocational Students}

Incentive way has a huge impact on students, teachers can use language incentive, example models, emotional incentives and other incentives to regain self-confidence, adjust their loss status as soon as possible, and devote themselves to learning and socializing, no longer indulging in the Internet, develop themselves on every side and enhance their own value.

\subsection{Language Incentive}

Language is an art, when teachers reasonably and effectively use language incentive in daily teaching, it will have a huge impact on higher vocational students. In daily classrooms, teachers should constantly infiltrate ideal sense into students, so that high-school students who lose confidence and feel inferiority can find their own ideals of life as soon as possible, and then students will have the learning motivation under the ideal promotion. Teachers should also instill equality for everyone concept into students, the level of university cannot determine the success of life, no matter where you are or where you are, you cannot give up on yourself. As long as you have confidence in yourself 
and willing to work hard, the fate of life can be changed, and the ideal of life can be realized. Teachers often communicate with students in positive language, which will rekindle the ideals of students' hearts, students will believe that their destiny can change and they have the right to pursue a better life. At this time, they will standardize their behavior and work hard to do what a good student should do; this plays a vital role in the development of higher vocational students.

\subsection{Example Incentive}

The influence of the example is huge, if a team has an example that can be imitated, the members of the team will continue to motivate themselves and develop towards the example, which plays an important role in the improvement of team overall strength. In the management of higher vocational students, example incentive also plays a role should not be overlooked. In higher vocational teaching, teachers can often tell students about motivational stories of celebrities, such as the success of Ma Yun and Bill Gates, etc., these celebrities have great influence and can stimulate the most primitive desire of students, they don't care about the gap in the degree, but will work hard for their ultimate goal. The celebrities' case has brought the self-confidence of higher vocational students back; they will use their knowledge, culture and their enthusiasm to realize their ambitions. For the choice of example, it is best to be a student with outstanding performance among high vocational students, which is conducive to other students to experience and closely contact.

\subsection{Emotional Incentive}

The so-called emotional incentive is that teachers should respect and trust higher vocational students enough in management. In the teaching, the teacher should have the same attitude toward higher vocational students as the undergraduate students, and do not discriminate them, because the students are equal. Teachers can usually arrange some small tasks to students, which not only express the teacher's trust for students, but also make the students feel their own value. Teachers can also take the initiative to participate in the activities of students, integrate with students and increase teacherstudent exchanges. Teachers must spare no praise language, in normal teaching, no matter whether students answer questions in the classroom right or wrong, they should encourage students more, because they can courageously answer questions, it is worthy of praise. Such emotional motivation can improve students' enthusiasm, make students change their attitudes towards teachers in the past, and regard teachers as friends, this is conducive to teachers' teaching work for higher vocational students, it is conducive to improving learning interest of higher vocational students, and make higher vocational students improve their results and eventually graduate smoothly.

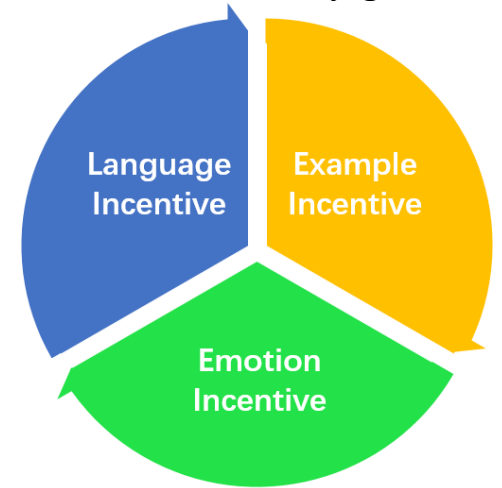

Fig. 2 Incentive methods of depression

\section{Conclusion}

The college entrance examination is only a small part of life experience, which cannot determine the fate of a person. Therefore, higher vocational students need teachers or schools use incentive way to manage students. In allusion to the problems of current higher vocational students' inferiority, loss of learning interest, and lack of self-discipline, the author suggests that language incentive, example incentive, emotional incentives and other incentives are used to eliminate students' inferiority and 
improve students' learning interest, standardize students' behavior, make students graduate smoothly, and realize their ideals of life. The management way of incentive teaching should also be promoted to the education of various schools as soon as possible, so that more students can learn with a better state and improve comprehensive quality of students.

\section{References}

[1]. Zhou Qiong. Explore the Effective Use of Incentive Way in the Management of Higher Vocational Students[J]. New Education Era, 2016, (26): 49.

[2]. Liu Juan. Discussion on the Effective Use of Appreciation Education in the Management of Higher Vocational Students[J]. Course Education Research, 2016, (8): 132.

[3]. Yin Fulong. How to Effectively Use Incentive Way in the Management of Higher Vocational Students[J]. Times Education, 2017, (11): 11-12. 